\title{
THE CHARACTERISTICS OF SHARIA COMPLIANCE IN THE SETTLEMENT OF SHARIA ECONOMIC DISPUTES IN INDONESIA
}

\author{
Fiska Silvia Raden Roro \\ Private Law Departement, Universitas Airlangga \\ Surabaya, Indonesia \\ fiska@fh.unair.ac.id \\ Ghansham Anand \\ Private Law Departement, Universitas Airlangga \\ Surabaya, Indonesia \\ ghansam@fh.unair.ac.id
}

Abstract- bstract---According to Article 1 point 12 of Law no. 21 of 2008 (of the Republic of Indonesia) concerning Sharia Banking (Supplement to State Gazette No. 94 of 2008, Supplement to State Gazette No. 4867) explains that Sharia Principles are Islamic Law Principles in banking activities based on Fatwas issued by institutions that set an agreement under Islamic law between any bank and other parties for the fund deposit and / or financing of business activities or other activities declared in accordance with sharia. In a business transaction, the principle of kafah is obligatory, meaning that sharia compliance shall apply from the contract signing until the end of its implementation, including its dispute settlement instrument in case of a sharia economic dispute in the future. As the global economy develops, communities of Islamic law (sharia) in some countries are compelled to contribute to the establishment laws that regulate contracts (shariacompliant financial documents) as the legal basis for sharia-compliant dispute settlement. On the other hand, law reform in sharia economy seems to be done in order to contribute the improvement of the law (in Indonesia). The parties who have entered into a sharia contract would expect that a dispute settlement be made in compliance with sharia

\author{
Kukuh Leksono Suminaring Aditya \\ Private Law Departement, Universitas Airlangga \\ Surabaya, Indonesia \\ kukuhleksonosa@fh.unair.ac.id
}

principles, which further detail the settlement arrangements pursuant to sharia (the appropriate legal rules under Islamic sharia / syariah perspective). On 22 December 2016, the Chief Justice of the Supreme Court of the Republic of Indonesia signed the Supreme Court Regulation No. 14 of 2016 concerning Procedures for Sharia-Compliant Dispute Settlement. However, this regulation is still far from meeting the expectations of disputing parties who are bound by sharia contracts and seeking a sharia/kaffahcompliant settlement because some factors therein are still in non-compliance with sharia principles. Therefore, this article will discuss the concept of sharia compliance, as well as non-sharia compliance in dispute settlement in Indonesia.

Keywords---Non-Sharia Compliance, Dispute Settlement, Sharia Economy.

\section{INTRODUCTION}

Ubi societas ubi ius, wherever there is society, there is a (governing) law. The creation of a single market of AEC (ASEAN Economic Community) will require a legal instrument that can align the interests and achievements of all parties involved. Some ASEAN countries have adopted sharia, for both country with civil law 
system and common law system. The rapid growth of sharia

finance industry in ASEAN countries is based on two factors: first is the fact that sharia is profitable sector for parties involved. It is a viable source to grow rapidly and it develops with an increasingly positive reputation for responsible management. Second is an increasing demand for sharia finance, which is influenced by the growth of number of Muslims in these countries. The Islamic law in ASEAN countries covers the following areas (i) Muslim family law, (ii) Bank and Non-bank Financial Industry, (iii) Halal Food, Beverage and Cosmetics Industry, (iv) Other aspects (hajj, zakat, waqaf and others).

The expansion of Islamic law is the result of the expansion of Islamic civilization and the migration of people in earlier times. As Glen argues that the exchange between Islamic law and other laws often occur under the constitution of the host country, the original local law is diluted by the adoption of sharia, which is opted to replace the previously prevailing law. The complete version of Glen's opinion is as the following:

Islamic population are now spread widely throughout the world as result of earlier expansion of Islamic civilization and as results of contemporary patterns of migration and conversion. The exchange among Islamic law and other laws that often takes place beneath a constitutional umbrella of host state, while identification of the umma becomes less precise, as host state law displace, in variable measure, application of the sharia.[1]

Indonesia has entered the free market of Southeast Asia or better known as ASEAN Economic Community (AEC) officially from January 1, 2016. Ten ASEAN member states in 2007 have agreed to create a single market in Southeast Asia. Ubi societas ubi ius, wherever there is a society, there is a (governing) law. The creation of this AEC single market will require a legal instrument that can harmonize the interests and the achievements of all involved parties. If the MEA truly becomes a society with a harmonized legal code, the barriers between national laws of its member states will gradually fade. Islamic law becomes one of the most viable alternatives to be a legal choice for investors in the Southeast Asian region. Sharia compliance has the advantages that obliges involved parties to be obedient and submissive in accordance with the sharia agreement that has been agreed upon. If a business contract needs to unite international parties with different jurisdiction background for asset and business transactions, then Islamic law that promotes sharia compliance on the choice of law and choice of forum can serve as the right solution.

\section{Religious Court as an Access of Court Facility}

With regard to access of court, Muslims and /or those who voluntarily accept the Islamic Law have been facilitated by the state with the existence of Religious Court at the municipality or regency level and Religious High Court at the provincial level in Indonesia. The Religious Judiciary, is translated from the term Godsdienstige Rechtspraak, derived from the word godsdienst meaning religion, worship or religious and the word rechtspraak meaning the judiciary, which is defined as the effort to seek seeking justice or settlement for a legal disputes conducted according to the rules and in certain institutions within court.

Definition of Religious Courts is a judicial forum for Muslims as listed in Article 1 point 1 of Law no. 50/2009 on the Second Amendment to Law no.7/ 1989 on Religious Courts (State Gazette of the Republic of Indonesia Year 1989 no. 49, Supplement to the State Gazette of the Republic of Indonesia no. 3400). In Article 1 point 2, it is stated that the Court is defined as religious court and religious high court in the religious judicial environment.

Based on Article 2 of Law now. 3/ 2006 on the Amendment of Law no. 7/1989 on Religious Courts (State Gazette of the Republic of Indonesia of 2006 no. 22, Supplement to the State Gazette of the Republic of Indonesia no. 4611), it is stipulated that the Religious Courts are one of the judicial authorities which can exercise its power to seek justice for the Muslim citizen on certain matters as referred to in this law.

From the above definition, it can be concluded that the Religious Judiciary is a state-made effort 
to seek justice or solve certain cases for the Muslim citizen through institutions that serve to exercise this judicial power in accordance with applicable legislation.[2]

\section{The Concept of Right to Access to Justice}

Access to court is not sufficient in the implementation of Islamic law. It also requires access to justice. In the perspective of Islamic law, according to Abdul Haseeb Ansari, [3] the right to access to justice is the right to obtain justice. Access to justice is a right that is regulated in Islamic law and is granted to all citizens within a country. This right is very important and valuable that Islam has given to human being. This principle has been mentioned in several verses of the Koran. Justice in Koranic Islamic Law is explicitly expressed in Surah AlImran verses 18 and 19, as the following:

Allah witnesses that there is no deity except Him, and so do the angels and those of knowledge - that He is maintaining creation in justice. There is no deity except Him, the Exalted in Might, the Wise. Indeed, the religion in the sight of Allah is Islam. In addition, those who were given the Scripture did not differ except after knowledge had come to them - out of jealous animosity between themselves. And whoever disbelieves in the verses of Allah, then indeed, Allah is swift in taking account

Not only God serves justice through the law rules set by $\mathrm{Him}$, but $\mathrm{He}$ command the jurists, judges, law enforcement officials, and witnesses in the trial to be fair and just, as stated in Koran Surah An Nisa verse 135, which is also curved on the wall of the entrance gate of Harvard University Law School, USA, which reads as the following:

$O$, you who have believed, be persistently standing firm in justice, witnesses for Allah, even if it were against yourselves or parents and relatives. Whether one is rich or poor, Allah is more worthy of both. So follow not personal inclination, lest you not be just. And if you distort your testimony or refuse to give it, then indeed Allah is ever, with what you do, Acquainted

Sami Zubaida expressed his opinion in his book "Law and Power in The Islamic World":
The political resonance of the shari'a, historically and at the present, is associated with it function as a language of justice. The sharia is much more than law in modern sense. It also function as a vocabulary of morality and justice, much used in political disputation over the ages and to the present."

Furthermore, the language used in Sharia is a language related to justice. Sharia emphasizes on justice and not solely on the law per se., Sharia should put justice above on all parties, and if it does not serve justice, it is not worth defined as "law". Sharia is not all about the legal aspect, but it also includes religion, moral and justice.

Despite the freedom of contact in the making of a contractual agreement, which allows a contract to be open, in which the parties involved may agree to various provisions of the agreement, the point of the agreement cannot violate the values of society related to propriety, justice and human rights.

The above background shows that sharia compliance serves as access to court and access to justice for Muslims and/or those who voluntarily subject to Islamic law in the settlement of sharia economic disputes. This requires a clear picture of the sharia compliance characteristics in a resolution of sharia economic dispute as a series of sharia enforcement of sharia contracts agreed upon in the beginning. The question is whether sharia compliance really has been reflected in the regulation in Indonesia related to dispute resolution in economy sector or vice versa, whether there is indication of nonsharia compliance on sharia economic dispute resolution in Indonesia? The author of this paper takes a normative approach for this research method. The issues will be analysed through two approaches: the statute approach and the conceptual approach. The use of these two approaches is intended to obtain a study related to the concept of sharia compliance in the choice of law and choice of forum in solving a sharia economic dispute as well as an analysis of the possibility of conflict of norms, or more precisely the indication of non-sharia compliance, related to sharia economic dispute in Indonesia.

Based on the above description, this article shall discuss the following issues: 
1. Characteristics of shariah compliance on Sharia Economic Dispute Settlement

2. Non Sharia Compliance on Sharia Economic Dispute Settlement in Indonesia.

\section{DISCUSSION}

\section{a. Characteristic of Sharia Compliance On Sharia Economic Dispute Settlement}

Compliance to Islamic law applies to both Muslim parties as well as non-Muslim parties who voluntarily subject themselves to the Islamic Law on a sharia-based contract. In a business transaction, the principle of kafah is obligatory, meaning that sharia compliance shall apply from the contract signing until the end of its implementation, including its dispute settlement instrument in case of a sharia economic dispute in the future.

Muslims who try to apply Islamic law thoroughly (kafah) in their legal acts, including in transaction and deal-making (muamalah), will seek to avoid usury in their business contract. Large banks are not considered sufficient in preparing their instruments to be shariacompliance-ready. Therefore, they are looking for experts to legalize their de facto conventional instruments as sharia-compliance. Religious leaders or scholars (ulama) continuously give inputs to the practice of Islamic banking, as it is not completely free of usury. Meanwhile the rule of I'adah al-nadhar provides the basis for reviewing the legal reasons that have been submitted by ulama on an occurring problem. In other words, the opinion of the earlier ulama may be disregarded, as it might not be applicable to the ever-changing situation. However, the development of these conditions must also be followed by the presence of new ulama opinion and these conditions must bring more benefits to the people. In Indonesia, these new opinions from the ulama are issued by the National Sharia Council of the Indonesian Council of Ulama (Dewan Syariah National Majelis Ulama Indonesia or DSN-MUI).

Islamic Banking Finance (IBF) is considered as a mere replacement of conventional banking terms, which uses classical Arabic terms and offers

identical services to clients but at a higher cost.[4] One study found that customer perceptions on sharia compliance play an important role in improving the image of sharia financial institutions, including banks. Better customer perception on the compliance and adherence level of the bank to the Sharia means a better conduct of religious value in doing business and a more positive image of the bank. Corporate image is a manifestation of how a company applies its core values in its business contracts.[5] There it is vital for sharia banking to seriously implement sharia compliance in business contract in addition to the exposure on its religious values. However the involved parties who choose to subject themselves to Islamic law but reside in a secular or a liberal democratic state may face a fundamental dilemma: on one hand there is the requirement to apply the sharia throughout, but on the other hand there is the duty as citizen to follow the secular laws of the country that separate the religious aspects from civil aspects.

For cross-country conventional transactions, Alex Saleh believes that the option to govern the legal resolution and dispute settlement is an important part of a document. All parties shall consider the legal consequences stemming from selecting the law of a particular jurisdiction, such as the issue of pertinent application of regulations in jurisdictions in which the parties choose to bring legal action, conflict of law and the enforcement of foreign judgments within the local jurisdiction. When all parties have opted to use Islamic finance structures, other jurisdictions may still govern the conventional (non-sharia) principles that refer to the creation of financial documents that will add to the complexity of the problem. It would be easier if the clauses listed in the document were directed to the sharia compliance.

Furthermore, Alex Saleh argues that if within the legal environment, the sharia judicial system cannot be upheld nor does it have absolute authority in implementing Islamic principles in Islamic finance documents, then the legal clauses, which govern and harness to the sharia principles will seem irrelevant and lacking 
of legal consequences. The best thing that has been increasingly adopted by legal practitioners in cross-state Islamic financial documents is to include representation that all the parties involved conclude that the agreement is in accordance with Sharia and provisions in which all the parties involved agree not to attempt to challenge the enforceability of the agreements on the basis of non-compliance with sharia principles. As a result, the governing legal clause will only provide the choice of law without sharia reference. In addition, many parties involved in cross-border trans-national sharia transactions increasingly opt for arbitration as a dispute resolution option to benefit from the flexibility offered and the opportunity to bring sharia and financial experts as arbitrators.

On the other hand, there are views against the application of sharia as a rule of law in a country, especially in western countries. According to Arsani William for Western societies, the word 'Sharia' brings up repulsive images of caning, execution, beheading, crimes against women, and other strict religious punishments. For the majority of people, Sharia is seen as the total opposite of the justice value standards in Western philosophy. For example in the UK, the sharia courts are considered a threat to the legal integrity of British democracy by promoting unequal treatment of women in British Islamic societies. However, the UK Sharia Court has been enforcing decisions under the Arbitration Law. Sharia decisions are implemented through the county and the High Court in the five districts where its rules are applicable. Many of these courts have issued mediation-related decisions for family matter since 2005. The UK Arbitration Law allows for alternative dispute resolution based on the willingness of the parties involved, including choosing religious law and sharia. The State may enforce the sharia related to family law and may recognize arbitral decision based on religious law.
Mohammad Shafik, as quoted by Arsani William, argues that Muslims are not asking British law to be altered, but requesting Sharia law to be recognized as an alternative. The followers of Islam see Sharia as the law of God emerged through divine revelation. They see Sharia as an embodiment of social justice and shall serve as the only source governing civil law including personal matters; decisions are to be adopted upon the basis of sharia. The use of sharia courts for civil law dispute resolution through arbitration in the UK is a growing controversy. Since August 2007, The British sharia courts have enacted hundreds of decisions on civil arbitration covering marriage, divorce, financial and domestic violence cases, meanwhile such cases are unheard of in British general courts. The establishment of sharia courts in Britain is a new phenomenon.[6]

In the case of Bahrain's Shamil Bank, the English and Wales Court of Appeal upheld the verdict of the subordinate courts stating that in an international contract the applicable law shall be the state law. A non-state law, such as lex mercatoria (merchant law) or sharia law is unacceptable. Sharia law in the contemporary context can be clearly categorized as transnational law. Some aspects of Islamic law are applicable to Muslims regardless the boundaries of the state [7] related to a number of general principles and detailed rules of a particular business contract (or commonly called nominate contracts), such as sale contract, loan contract, grant contract, etc. These principles and rules may be called the lex mercatoria of Islam, which shall automatically apply to international trade contracts between the parties if approved. From the general principles, the most important is the principle of pacta sunt servanda, where the parties must obey what is already in the contract. It is based on the Koranic command to honour a promise. Contracts are allowed by sharia except for riba (usury), gharar (uncertainty) and maysir (gambling) which are explicitly prohibited. If 
a contract involves any of these three, it is declared invalid which is to keep the sense of justice for all parties involved.[8]

According to Imani Jaafar, Muslim community is a growing segment in Minnesota where it is estimated between 20,000 to 130,000 Muslims are living in Minnesota. The notion of of basic practice of Islamic Law, in this case sharia contract for residential financing, will be useful for lawyers who currently serve or want to expand their practice to serve Muslim clients. Muslims who opt for sharia contract are growing steadily and Islamic law becomes a necessity for this population. Many practitioners are open to these requests to explore Islamic law to connect with the belief system of Muslims. This knowledge can be gained through lectures, community outreach, or even from reading reliable sources, including the Koran and the writings by those who are eligible to interpret the contents. It is also important for lawyers to be capable in providing legal advice to Muslim clients who come to their office and to undertake their request after the clients declare their intention to have their case resolved in sharia law. It is not easy to direct clients to be aligned with the religious courts, but lawyers can dedicate their time to work on Islamic legal issues and can find ways to deliver effective solutions by adjusting Islamic financial documents that can answer the clients' unique requests.

According to Colón, the rapid growth of Islamic finance will require an international legal system to develop an understanding of the fundamentals of sharia business transactions. Judges in countries with no history of Islamic law should compare the case to conventional cases with the common practice in their country, before comparing it with Islamic law in the financial sector to accurately assess the commercial objectives of sharia compliance in business law. The rules of the forum, specifically for Islamic finance, show the importance of statements that give the effect of the Islamic legal law than some mere proverbial purposes. For example, a contract should only apply as long as it is consistent with sharia. The expectation is that Islamic law and national law can go together without violating the existing principles. No more than one law can be applied to accommodate the request of the parties involved, to govern a binding contract between the parties.

Courts in countries that are not legally influenced by Islamic law have analysed the issue of sharia through the opinions of Islamic law scholars, to decide upon the case of sharia in non-Islamic courts. This raises the risk where the general courts are not seeking to find the basic definition and principles in sharia economic transactions. Consequently, domestic parties may prefer to incorporate standards issued by AAOIFI or other institutions, which release standards on sharia transactions.

The need for legal instruments for the settlement of sharia disputes cannot be avoided. In the few decades, the sharia arbitrations in many Middle East countries have expressed their doubts at international arbitrations as a forum to settle a sharia economic dispute. This brings awareness to parties from Western countries to have a better understanding of the basic principles of Sharia law and how these principles have influenced the laws in the Islam-influenced countries. This has brought a brief introduction to sharia principles, introduction to ICSID arbitration, and consideration to make sharia as a "choice of law" in arbitration subject to ICSID, where the provisions from ICSID are generally not against the principles found in sharia. As a result, the principles followed by countries using the sharia are put into consideration and have a role in assisting the further development of international trade.[9]

The position of sharia as a binding legal rule for Muslims is recognized as a major belief system for Muslim worldwide. The implementation will not be constrained as long as there is a supporting social and political legal system for the interest of Muslims in applying sharia compliance. If not, then the shariah will deal with the manipulation of the greater and stronger legal 
and political interests. This is in line with the claim from Feener:[10]

Sharia is particularly powerful for providing such binding rules of conduct because it is, on one level, a sufficiently abstract notion to appeal to anyone who would consider him or herself Muslim. At the same time, however, under this broad assent to Sharī'a as an ideal, there are immense spaces for the elaboration of very specific positions on a wide range of social and political-as well as more specifically religious-issues. Such a situation allows the possibility for great manipulation by certain powerful interests.

Litigation in cross border transactions is sometimes difficult to avoid. There will be legal uncertainty and ambiguity without identifying the governing laws and appropriate forums to resolve disputes arising from interstate transactions. Thus, the application of both the choice of law and the choice of forums in cross-border transactions in sharia finance should have a comprehensive and efficient international standard in the form of a set of rules governing sharia banking and other non-bank financial industry including the arrangements of financial products. The forum chosen for settlement of disputes in Islamic financial cross-border transactions shall also be subject to sharia. International sharia standards are required as a basis for choice of law and choice of forum.[11] If this sharia compliance is facilitated, the parties will automatically choose the international sharia standard as the basis of choice of law and choice of forum in their commercial contract in order to accommodate the application of kafah principle.

Several countries have legalized Islamic as a separated form of law from the conventional law, for example, sharia-banking law, which is separated from conventional banking law, although but the application still, raises the dualism of authority and disparity of decision in the settlement of sharia economic dispute. Even if the parties agree to sign a contract based on sharia principles, many problems remain related to the rule of law, the competence of the courts in dispute resolution, the infrastructure, and the resources and the expertise to interpret and enforce the Islamic economic/financial transaction documents. In certain countries where the religious judicial system (sharia) exists, the application of Islamic law is limited only to traditional jurisdictions to resolve cases related to the law of family, marriage and inheritance. Supposedly, Muslim community or those who agree to abide by a sharia contract shall be governed by the provisions of the law in harmony with sharia. Should a dispute emerges; the judge should make sharia as a source of law to resolve the matter. For these people, justice cannot be realized if the settlement is achieved through laws and judicial procedures that are not in line with the principles of sharia.

\section{a. Sharia-Compliant From Beginning to End, Including Choice of Law and Choice of Forum}

The freedom of contracting as stipulated in Article 1338 Burgerlijk Wetboek (BW) provides the right and opportunity for the parties involved to make the choice of law and in relation to civil cases may choose the domicile for the settlement as stipulated in Article 24 of BW. If in the end all parties agree to submit and to be bound by Islamic law in signing their contract, this shall bring the legal consequences to the right of choice of forum. This means sharia-compliant from start to finish (the application of kafah principle). The principle of kafah can only be achieved if the awareness level for the implementation of sharia compliance remains high from the beginning to the end of the contracts.

In addition to the freedom of contract, which gives the right and opportunity for the parties to exercise the choice of law that leads to submission and attachment to Islamic law in the contract signing, good faith must be present from the choice of law to the choice of forum in the event of dispute. This will lead to the use of Islamic law as the legal basis from beginning to end. The principle of kafah can only be achieved if the awareness level for the 
implementation of sharia compliance remains high from the beginning to the end of the contracts.

Some of the things that indicate the nonsharia compliance above require the enforcement of the principle of good faith, which comes from the will of all parties involved, manifested in the sharia contract. By applying the principle of good faith in an agreement, in both conventional and sharia law scheme, the execution of a contract might avoid unnecessary dispute. Koran, as the main source of sharia law, aims to set the basic standards for the Muslim community and guide the members of community in terms of their rights and responsibilities. At that time the revelation of Koran, it was intended to provide a set of progressive principles that were in line with the reformist ideas. These progressive principles include good faith, compassion, justice and religious ethics. In fact, of the 6000 verses in the Koran, 80 verses are of a strictly legal nature.

Nie Burgerlijk Weboek (NBW) requires the parties who entered into an agreement to act in accordance with reasonableness and equity. It can be said that good faith should be used not only in a contract, but also in all legal obligations. If all parties involved express their good faith in carrying out their legal obligations, then the disputes in the future may be prevented, or if in the end a dispute arises, then by keeping the principle of good faith, they can provide the best legal solutions as all parties desired by achieving the sense of justice and equality.

From the description above, it appears that good faith is a mandatory to be present from the beginning of the establishment of an agreement, the execution phase until the resolution of all emerging disputes.

Omar T. Mo believes that sharia compliance-at-will covers the principles of sharia compliance itself, recognition or acknowledgment of submission to the rule of Islamic law and enforcement that includes the implementation and the enforcement of the contract's contents.
This is in line with the opinion of Tun Abdul Hamid Mohamad20 who stated that every sharia financial transaction should be Shariah-compliant from beginning to end". He further explained that:

Muslims (including the parties in sharia contract) should not lose sight of that intention otherwise Islamic finance could lose its direction, is corrupted or even hijacked. That calls for:

(1) the product itself has to be shariacompliant;

(2) the implementation has to be shariacompliant;

(3) the settlement of disputes has to be shariah compliant.

Awareness for the sharia compliance does not only cover the objects in the contract (either for goods or services), but also on the accomplishment of all parties involved or the implementation of the approved contracts and includes the implementation of sharia compliance in the instruments used for sharia dispute resolution.

Related to the out-of-court settlement of a dispute in the case of sharia-compliance, Omar T. Mo further explained that there are many advantages to choosing Islamic arbitration for the public in the United States. Arbitration gives individuals the opportunity to resolve disputes in a manner, which is consistent with their religious beliefs while retaining the benefits of court protection and law enforcement. These advantages includes, first, when the dispute emerges, this contract will be analysed by an arbitration body composed of Islamic law experts. Second, the parties have the advantage of choosing the mahdzab of Islamic law to interpret the contract or the dispute between the parties engaged. Without an arbitration clause, the conflict will be resolved in US courts where the judge may not be familiar with the complexities and different schools of Mahdzab contained in Islamic law, thus the interpretation of these judges may unlikely to be enacted and not endorsed by the parties engaged to this sharia contract. A sharia economic law dispute will be more likely to be 
avoided by the inclusion of the sharia arbitration clause, as it only allows Islamic law experts who are deemed eligible to make decisions on the dispute. Islamic law experts are expected to create decisions that can resolve disputes and legal issues that are at the root of the problem in a sharia contract. If the parties wish to comply with sharia law in all its forms within a series of economic transactions, then the arbitration will ensure and enforce the sharia compliance. Since the parties have subjected themselves to sharia on their contracts, then the sharia determines the parameters of the rights and obligations arising from the contract, and not only the intentions of the parties that count. Islamic jurisprudence.[12] must determine the parameters of rights and duties and identify the rights of these parties in the event of a dispute. The Islamic law experts order the parties to select the choice of forum, which makes Islamic law as its rules, for example for this case is the Islamic arbitration, in order to apply the sharia compliance within the contract they have signed.

The legal arrangement related to sharia in Indonesia, is provided in Article 1 point 12 of Law no. 21 of 2008 on Sharia Banking, which explains that:

Sharia Principles are Islamic Law Principles in banking activities based on Fatwa issued by institutions that set an agreement based on Islamic law between the Bank and other parties for fund deposit, financing of business activities or other activities declared in accordance with sharia.

In a sharia business transaction, it is necessary to apply the principle of kafah, which means that from the beginning of the contract signing until the end of its implementation, everything shall be subject to sharia, including the dispute settlement in the future. Following the development of the world economy, some countries have shown the needs sharia legal instrument to cater the community as a regulating law in a contract making (or in the creation of Islamic financial documents) which shall serve as the legal basis for the settlement in the case of a sharia economic dispute. This shows the importance of the discussion of Islamic law as the source of legal basis for sharia contract making and as a law, which regulates dispute resolution process both nationally and internationally. It can be concluded that the characteristics of sharia compliance in the effort to resolve a sharia economic dispute are reflected in:

a. Sharia Compliance in Contract Making (Choice of Law)

b. Sharia Compliance in Choice of Forum either through litigation or non-litigation

c. Sharia Compliance in handling of default or delays for debt repayment (Ta'widh)

d. Sharia Compliance in the execution of sharia-based Mortgage Rights

e. Sharia Compliance in Taflis (Bankruptcy in sharia)

\section{b. Non-Sharia Compliance in Sharia Economic Dispute Settlement in Indonesia}

The following subchapter will discuss the indication of non-sharia compliance on sharia economic dispute settlement in Indonesia:

Judicial Review of Law no. 21/2008 on Sharia Banking (Supplement to the State Gazette of 2008 No. 94, Supplement to the State Gazette No. 4867)

The politics of sharia economic law in Indonesia was allegedly not fully supportive of the Sharia compliance in the prevailing laws and regulations. The implementation of the Islamic legal system is still deemed not in the kafah and considered unjust to the Muslims in Indonesia. This condition resulted in a Judicial Review taken by the Constitutional Court against Article 5 paragraph (2) and paragraph (3) of Law no. $21 / 2008$ on Sharia Banking [Supplement to the State Gazette of 2008 no. 94, Supplement to the State Gazette no. 4867), hereinafter referred to as Law no. 21/2008 on Sharia Banking] against the Constitution of the Republic of Indonesia.

The issuance of Law No. 3/2006 on the First Amendment of Law no. 7/1989 on 
Religious Court (State Gazette of the Republic of Indonesia of 2006 no. 22, Supplement to State Gazette of the Republic of Indonesia no. 4611), hereinafter referred to as Law no. 3/2006, affirms the Religious Courts as the only judiciary with the absolute authority to examine and decide cases related to sharia economic disputes. However, although it is clearly stated by article 49 letter $i$ of Law no. 3/2006 on the authority of Religious Courts in examining and deciding cases of sharia economy, it turns out that Law no. 21/ 2008 on Sharia Banking provides a legal choice to settle disputes in a district, non-religious court. This shall not problematic for the settlement of sharia economic disputes through peaceful and nonlitigative manner. However, it is a different case for the settlement of sharia economic disputes, which goes through litigation process in a district court. This is considered a violation of the constitutional rights of citizens. This reason served as the base of examination by the Constitutional Court on Article 5 paragraph (2) and paragraph (3) of Law no. 21/ 2008 on Sharia Banking against the Constitution of the Republic of Indonesia, which is recorded as Case no. 93/PUU-X/2012. With the dualism of the court competency as mentioned above, it will obviously create confusion among people who seek for justice and resolution in a sharia economic dispute. The decision of the Constitutional Court no. 92/PUU-X / 2012 finally confirmed the authority of the Religious Courts by stating that Article 55 paragraph (2) of Law no. 21/ 2008 on Sharia Banking has no longer legal binding power. As a result, the Religious Courts are the only judicial institutions with absolute competence to settle a dispute over the matter of sharia banking. However, the parties in dispute are still allowed to select non-litigation path through discussion/negotiation, mediation (sulh) or through arbitration institutions (tahkim), provided that it has been agreed by the disputing parties prior or after the dispute and that it is still in line with the principles of sharia.

Regulation of the Supreme Court of the Republic of Indonesia no. 2/2008 on the Compilation of Sharia Economic Law
Since the issuance of Regulation of the Supreme Court of the Republic of Indonesia no. 2/2008 on the Compilation of Sharia Economic Law (Kompilasi Hukum Ekonomi Syariah or KHES), between 2008 to 2015, from nine decisions, there are seven decisions that ruled

\begin{tabular}{|c|c|c|c|c|c|c|}
\hline \multirow[b]{2}{*}{ NO } & \multirow[b]{2}{*}{$\begin{array}{l}\text { DISPUTING } \\
\text { PARTIES }\end{array}$} & \multirow[b]{2}{*}{$\begin{array}{l}\text { NO. OF COURT } \\
\text { DECISION }\end{array}$} & \multirow[b]{2}{*}{$\begin{array}{l}\text { TYPE OF } \\
\text { DISPUTE }\end{array}$} & \multicolumn{3}{|c|}{ SOURCE OF LAW } \\
\hline & & & & KHES & BW & \begin{tabular}{|l} 
Fatwa \\
of \\
DSN- \\
MUI \\
\end{tabular} \\
\hline 1 & $\begin{array}{lr}\text { PT. } & \text { BPR } \\
\text { Syariah } & \text { Tulen } \\
\text { Amanah } & \text { vs } \\
\text { Client; } & \\
\end{array}$ & $\begin{array}{l}\text { 419/Pdt.G/2008/PA. } \\
\text { SEL }\end{array}$ & $\begin{array}{l}\text { Breach of } \\
\text { Mudharab } \\
\text { ah contract }\end{array}$ & Yes & Yes & Yes \\
\hline 2 & $\begin{array}{l}\text { Bank } \\
\text { Muamalat } \\
\text { Indonesia vs } \\
\text { PT. Asuransi } \\
\text { Takaful } \\
\text { Umum; }\end{array}$ & $\begin{array}{l}\text { 1221/Pdt.G/2009/PA } \\
\text {.JS }\end{array}$ & $\begin{array}{l}\text { Breach of } \\
\text { insurance } \\
\text { contract }\end{array}$ & Yes & & Yes \\
\hline 3 & $\begin{array}{lr}\text { PT. } & \text { BPR } \\
\text { Syariah } & \text { vs } \\
\text { Client } & \\
\end{array}$ & \begin{tabular}{|l|} 
882/Pdt.G/2010/PA. \\
Sit \\
\end{tabular} & $\begin{array}{l}\text { Breach of } \\
\text { Musharak } \\
\text { ah contract }\end{array}$ & No & Yes & \\
\hline 4 & $\begin{array}{l}\text { Client vs KSU } \\
\text { Bait Mal wa } \\
\text { Tamwil; }\end{array}$ & $\begin{array}{l}\text { 463/Pdt.G./2011/PN. } \\
\text { Btl }\end{array}$ & $\begin{array}{l}\text { Breach of } \\
\text { Mudharab } \\
\text { ah contract }\end{array}$ & Yes & & \\
\hline 5 & $\begin{array}{l}\text { KSU BMT } \\
\text { Bina Sejahtera } \\
\text { Mandiri vs } \\
\text { Client }\end{array}$ & $\begin{array}{l}\text { 318/Pdt.G/2011/PA. } \\
\text { Btl }\end{array}$ & $\begin{array}{l}\text { Breach of } \\
\text { Mudharab } \\
\text { ah contract }\end{array}$ & Yes & Yes & Yes \\
\hline 6 & $\begin{array}{l}\text { BPRS Buana } \\
\text { Mitra Perwira } \\
\text { vs Client } \\
\end{array}$ & $\begin{array}{l}\text { 1740/Pdt.G/2011/PA } \\
\text { Pbg }\end{array}$ & $\begin{array}{l}\text { Breach of } \\
\text { Mudharab } \\
\text { ah contract }\end{array}$ & Yes & & \\
\hline 7 & $\begin{array}{l}\text { Client vs KSU } \\
\text { BMT Islam } \\
\text { Sejahtera }\end{array}$ & $\begin{array}{l}\text { 700/Pdt.G/2011/PA. } \\
\text { Btl }\end{array}$ & $\begin{array}{l}\text { Breach of } \\
\text { Mudharab } \\
\text { ah contract }\end{array}$ & No & & Yes \\
\hline 8 & $\begin{array}{l}\text { Client's spouse } \\
\text { vs Bank Sumut } \\
\text { Syariah } \\
\text { Padangsidimpu } \\
\text { an Branch } \\
\end{array}$ & $\begin{array}{l}\text { 967/Pdt.G/2012/PA. } \\
\text { Mdn } \\
\end{array}$ & $\begin{array}{l}\text { Breach of } \\
\text { Mudharab } \\
\text { ah contract }\end{array}$ & Yes & & Yes \\
\hline 9 & $\begin{array}{ll}\text { PT. BNI } & \text { Byariah } \\
\text { Syecapem } & \\
\text { Mikro } & \\
\end{array}$ & $\begin{array}{l}\text { 964/Pdt.G/2014/PA. } \\
\text { ME }\end{array}$ & $\begin{array}{l}\text { Breach of } \\
\text { Mudharab } \\
\text { ah contract }\end{array}$ & Yes & Yes & Yes \\
\hline
\end{tabular}

KHES as a source of law in sharia economic dispute resolution, as presented in the following table:

Table 1: Dispute in Sharia Economy 23

The table above at a glance shows that the Compilation of Sharia Economic Law (KHES) has been applied by the majority of judges in religious court, where 7 (seven) out of 9 (nine) cases are based on this source of law. However, it should be noted that the existence of the Compilation of Sharia Economic Laws in fact does not rule out the Civil Code (Burgerlijk Wetboek) as a source of conventional civil law. Thus, there is still the potential mix-up of the sharia and conventional finance law as shown in the table above, where the dispute of eight cases occurred are related to sharia based financing. This is what created confusion as these sharia economy or business dispute resolutions are resolved using the conventional law procedure, which in Indonesia is basically a derivation from 
the Dutch Law that is not in harmony with the principles of sharia.

Abdul Manan views Islamic economy as a "social science which studies the economic problems of people imbued with the values of Islam".24 Values of Islam in this opinion, according to Lukman Santoso, can be based on the rules of tafriq al-halal min al-haram and i'adah al-nadhar, where tafriq al-halal min alharam is defined as the separation of halal elements from the haram, given that the practice of sharia economy in still involves a certain degree of usury. Therefore, a "strict separation" is required between the practices of economic activities that are halal and haram. In this study, the authors found an interesting case of a lender in the village who demanded the borrower to repay the monthly installment plus a "bonus" to the lender. The author then asked the person what is the basis of this "bonus", the surprisingly the answer is that since Islam prohibits usury, the lender therefore applies this "bonus" system. This is certainly a form of deviation in sharia principles applied in economic activities. Obviously, there is a mixing of halal and haram elements in this practice because there is no clear boundaries and rules about the haram element in sharia economic practice. In a conventional business where usury is legal, the position of risk and profit only favours one side and are not equally earned and borne by all parties engaged. The practice of usury does not satisfy the sense of justice and therefore is forbidden by sharia. In contrast, a sharia-based business transaction is using the principle of loss and profit sharing where the risks and benefits are equally distributed between the capital owners and the capital manager. On this matter, Saleem expressed his views:

.. The objectives of shariah that wealth should benefit not only owner, but also the other contracting party and the society as a whole. This is best achieved when the risk and rewards of investment are shared between the fund owner and its user. In contrast, usury only guarantees a certain predetermined rate of return to the fund owner and ignores its user. A needy person who borrows money for consumption purposes is required to pay back more than what he has borrowed and a person who borrows capital for trade and business has to take the risk of loss in case the business fails. The capital provider is guaranteed his capital plus interest and protected from losses. The risks of investment are entirely shifted to the borrowers.

If one of the parties in the contract, in this case the borrower, is not able repay his debts to the creditors, then the borrower will be declared in a state of bankruptcy, usually due to a financial distress from the declining business. 26 A dispute settlement effort will distinguish between a breach of contract (lack of intention to make the repayment) and an inability to repay the debt (in which the bankruptcy application can be submitted by two creditors).

\section{Supreme Court Regulation no. 14/2016 on Procedures for Dispute Settlement on Sharia Economy}

Law reform in sharia economy shall take place in order to contribute improvement of the law. This is in accordance with the non-Law provisions related to the sharia economic dispute. On December 22, 2016, the Chief Justice of the Supreme Court of the Republic of Indonesia has signed the Supreme Court Regulation (Perma) no. 14/2016 on Procedures for Dispute Settlement on Sharia Economics. Unfortunately, this Perma no. 14/2016 is still far from the expectations of the parties who subject themselves to the sharia law and who want to resolve the dispute in a manner of shar'i and kaffah, as several indications on the non-sharia compliance, among others:

a. This regulation is still subject to the updated Reglemen of Indonesia (Regulation of Law for Region Outside of Java and Madura or Het Herziene Inlandsch Reglement/Regular Tot Regeling Van Het Rechtswezen In De Gewesten Buiten Java En Madura). It is only appropriate that legal instrument for sharia economic dispute settlement to no longer use the rules of the Dutch colonial legacy, where the Dutch were subject to civil law system. It is expected that the principle of sharia compliance will be applied to the settlement of sharia disputes. In addition, today's business transactions are mostly transnational and cross-country where the choice of law for the contract and the choice 
of forum for the dispute settlement should be universally accepted. In this case, the parties are not simply confronted by the choice between the civil law system and common law system.

b. This regulation has yet to provide a detailed and shar'i arrangement, which is in accordance with sharia law perspective, related to a case of breach of contract resulting in default, or delay in debt repayment, which is the initial and main reason of many sharia economic disputes.

c. The handling of a bankruptcy process is still not set in this regulation, therefore it cannot be used as a guideline in handling a taflis case and such case falls under the authority of commercial court and not religious court. This dualism on the applicable law in handling cases related to sharia economic practice has a systemic impact on the disparity of decisions in particular, and the application of the procedural law in general. This will result in many parties involved in the sharia economic sector to subject to the conventional bankruptcy law in Law no. 37/2004 on Bankruptcy and Suspension of Payment Liability (State Gazette of the Republic of Indonesia of 2004 no. 131, Supplement to State Gazette no 4443), hereinafter referred to as the Law of Bankruptcy and Suspension of Payment Liability.

The concept of bankruptcy as stipulated in Article 1 point 1 Law no. 37/2004 on Bankruptcy and Suspension of Payment Liability (State Gazette of the Republic of Indonesia of 2004 no. 131, Supplement to State Gazette no. 4443, hereinafter referred to as the Bankruptcy Law stipulates that bankruptcy is: general confiscation of all the wealth of a declared debtor in which the management and procedure is carried out by the Curator under the supervision of the Supervisory Judge.

From the perspective of Islamic law, in Fiqh[13], bankruptcy has its own term called attaflis. Etymologically at-taflis means bankruptcy, in loss or falling into poverty. A bankrupt person is called a muflis, a person in loss whose debt is greater than his asset, which in the Bankruptcy Law Article 1 point 4 is defined as Debtor declared bankrupt. In the
Compilation of Sharia Economic Law, muflis is identified with incompetence in committing the acts of law, which is mentioned in article 1 point 6 as Muwalla. 28 In terminology of fiqh scholars, At-taflis (determination of bankruptcy) is defined by the ulama as with: "The judge's decision to prohibit a person to act law upon his assets".29 The prohibition is issued, as the debtor was involved in debt that covers or even exceeds the entire assets. This step is taken for a person in a state of bankruptcy or taflis and that person in therefore prohibition or freezing of the assets and the actions (al-hajr). The terminology of al-hajr means the prohibition of a person in spending his wealth. This is due to the fact that within the assets lie the rights of others, or the creditor. The basis of al -hajr in Islam is the Hadist Shahih Bukhari and Hadist Shahih Muslim where Prophet Muhammad SAW said: "Whoever finds his exact property with a man who has become bankrupt, and then he has more right to it than anyone else".

Non-sharia compliance is also apparent from the lack of recognition of the authority of religious jurisdiction in solving bankruptcy, which is part of case settlement in sharia economy. This is reflected in Putusan Kepailitan (Bankruptcy Decision) No: 7/Pailit/2011/PU Niaga Central Jakarta. This verdict is even strengthened by the Decision of the Supreme Court of the Republic of Indonesia No: 346F/PDT.SUS/2011, despite the fact that within a case of bankruptcy lie the elements of sharia economy. The decision of the Supreme Court is issued five years after the enactment of religious jurisdiction in the sharia economy as stipulated in Article 49 of Law no. 3/ 2006.

d. This regulation has not set the procedures for the execution of mortgages that follows the creation of a sharia contract as manifested in Islamic financial transaction documents. Referring to Article 49 of Law no. 3/2006, the execution of mortgages that is based on sharia contract falls under the absolute authority of religious court. In fact in 2013, which is seven years since Law no. 3/ 2006 was enacted which has clearly stated the authority of Religious Courts in sharia economy; there are still executions of mortgage objects on sharia-based financing 
by the district court. The execution of mortgage objects of a murabahah financing in one of the sharia banks was not taken by a religious court, but based on the Decision of Malang District Court no.211/PDT.G/2013/PN.MLG.

\section{CONCLUSION}

a. The characteristic of sharia compliance in a business transaction is the principle of kafah which means complete compliance to sharia from the beginning of contract signing until the end of the implementation including the instrument for dispute settlement in the future (from beginning to the end, including the choice of law and choice of forum). Following the development of the world economy, some countries began to show the needs of sharia as a regulating law for contract making (and for creation of Islamic financial documents) and as the legal basis in the settlement of a sharia economic dispute. It can be concluded that the characteristics of sharia compliance in the effort to resolve a sharia economic dispute are reflected in (i)Sharia Compliance in Contract Making (Choice of Law), (ii) Sharia Compliance's Choice of Forum either through litigation or non-litigation, (iii) Sharia Compliance in handling default or delays for debt repayment (Ta'widh), (iv) Sharia Compliance in the execution of Sharia-based Mortgage Rights, (v) Sharia Compliance in Taflis (Bankruptcy in sharia).

b. Within the legal system in Indonesia related to the settlement of sharia economic dispute, the non-sharia compliance is still reflected in the regulation, in other words, the existing laws for dispute resolution on sharia economy still indicate the opportunity of non-sharia compliance. For example, the Perma no. 14/2016 on Procedures for Settlement of Sharia Economic Dispute still has not answered the need for the sense of justice (access to justice) by Muslims and/or parties who have subjected themselves to sharia law. Those who expect the principles of kafah from the beginning to the end in their muamalah (starting from the choice of law to the choice of forum) will end up having to submit to the general judicial laws and other conventional laws that are not sharia compliant. This includes the nonsharia compliance on the execution of mortgage objects from a sharia-based financing, the non-sharia compliance on the instruments of taflis, and the non-sharia compliance on a breach of contract, default and delay of debt repayment that do not comply with the existing Ta'zir and Ta'widh instruments.

\section{REFERENCES}

[1] H.Patrick Glenn, "Legal Traditions of The World", 4th Edition, Oxford University Inc.Newyork,2010. Page .226-227.

[2] ibid

[3] Abdul Haseeb Ansari dan R. K. Salman, Human Rights, Human Dignity And Justice: The Islamic Perspective, Journal of Islamic Law Review, Vol. 7, No. 1, June 2011,h.101-102.

[4] 5Feisal Khan ,How 'Islamic' is Islamic Banking, Journal of Economic Behavior \& Organization, Dept. of Economics, Hobart and William Smith Colleges, United States, 2010,hal.818.

[5] Risca Fitri Ayuni et al, Role Of Religion Motives And Brand Image Towards Consumer Satisfaction And Consumer Loyalty Of Islamic Banking , The International Journal of Accounting and Business Society Vol. 23, 2015,page 65 .

[6] Arsani William, An Unjust Doctrine of Civil Arbitration: Sharia Courts in Canada and England, Stanford Journal of International Relations, Vol. XI No. 2, 2010,page 42-44.

[7] Anowar Zahid and Hasani Mohd Ali, Shari'ah As A Choice Of Law In International Islamic Financial Contracts Shamil Bank Of Bahrain Case Revisited,US-China Law Review Vol.10,2013.

[8] Anowar Zahid and Hasani Mohd Ali, Shari'ah As A Choice Of Law In International Islamic Financial Contracts:Shamil Bank Of Bahrain Case Revisited,US-China Law Review Vol.10,2013, page. 27 dan 3

[9] Andrew Smolik, "Effect of Shari'a on the Dispute Resolution", Journal of Dispute Resolution, Vol. 2010, Issue 1,Article 8, 2010, page .174 . 
[10] R. Michael Feener,Social Engineering Through Shari'a: Islamic Law And StateDirected Da'wa In Contemporary Aceh , Indonesia law Review, Vol. 3,2013, page .308.

[11] Aznan Hassan et al, The Application of Choice of Law and Choice of Forum Clauses to Islamic Banking and Financial Cross Border Transactions, Australian Journal of Basic and Applied Sciences, 6(11),2012, h.370.

[12] The referred Islamic law experts in Indonesia are the members of National Sharia Council of the Indonesian Council of Ulama (Dewan Syariah Nasional Majelis Ulama Indonesia or DSN-MUI) who are in charge in determining the halal or the haram parameter of a contract, through a fatwa released by the Council.

[13] Etymologically, "fiqh" is derived from the term "faqihayafqahu-fiqhan" which means to know or to comprehend. Al-Fiqh, etymologically is defined as knowing something by having the full understand of the matter (al'ilmbisya'ima'a al-fahm). Fiqh is the study of the teachings of Islam called the Sharia that is amaliah (practical) which is obtained from systematic grounds. 